\title{
Synthesis, Characterization and In-Silico Analysis of New 2-Pyrazolines
}

\author{
T. Saroja ${ }^{1}$, R. M. Ezhilarasi ${ }^{1 *}$, V. Selvamani ${ }^{2}$, S. Mahalakshmi ${ }^{3}$ \\ ${ }^{1}$ Department of Chemistry, Guru Nanak College (Autonomous), Velachery, Chennai - 600042, \\ India \\ ${ }^{2}$ Department of Chemistry, Sri Sarada Niketan College of Arts \& Science for Women, Salem - \\ 636354, India \\ ${ }^{3}$ Department of Chemistry, Pachaiyappa's College, Chennai, India
}

Received 9 May 2020, accepted in final revised form 1 October 2020

\begin{abstract}
Heterocyclic compounds such as pyrazolines, pyrimidines, oxazole and isoxazole exhibit different pharmacological activities. The current study involves synthesis of new 2pyrazolines. The synthesis involves the cyclocondensation reaction of substituted chalcones with (4-fluorophenylthio)acetic acid hydrazide (FTAH) under reflux. The chalcones (C1-C7 / 1a-1g) were synthesized from the reaction of substituted acetophenone with substituted benzaldehyde and FTAH was prepared from 4-fluro thiophenol. New 2-pyrazolines were obtained in good yields (60-70 \%). All the compounds were characterized by FT-IR, ${ }^{1} \mathrm{H},{ }^{13} \mathrm{C}$ NMR and mass spectra. PASS analysis was carried out for the 2-pyrazolines synthesized (P1-P7 / 3a-3g).
\end{abstract}

Keywords: 2-pyrazolines; PASS; Chalcones; Hydrazide.

() 2021 JSR Publications. ISSN: 2070-0237 (Print); 2070-0245 (Online). All rights reserved. doi: http://dx.doi.org/10.3329/jsr.v13i1.46995 J. Sci. Res. 13 (1), 183-194 (2021)

\section{Introduction}

Pyrazolines are nitrogen containing five membered heterocyclic compounds [1] having wide range of biological activities such as cytotoxic [2], anti-platelet, anti-microbial [3,4], anti-tubercular [5], anti-inflammatory [5-7], anti-amoebic [8], hypotensive [9], antidepressant [10], antiviral [11], anti-cancer [12], anti-proliferative [13], anthelmintics [14], antioxidant [5], analgesic [15] and herbicidal activity [16]. The stability and biological activity motivated the researcher to synthesise and study more pyrazoline derivatives $[4,16]$.

\footnotetext{
Corresponding author: ezhilarchana@gmail.com
} 
2-pyrazolines can be prepared by 1,3-dipolar addition, hydrozone formation in the presence of $\mathrm{HCl} /$ glacial acetic acid in ethanol, cycloaddition, reaction between arylhydrazine and Mannich base and one pot cyclocondensation between chalcone and hydrazine derivatives either by conventional or non-conventional method [17-21]. A number of pyrazolines prepared from hydrazines, arylhydrazines and a few acid hydrazides are reported in literature [4,19,22-23]. Among the various synthetic strategies reported, one pot cyclic condensation between chalcones and appropriate acid hydrazide seems to be more promising and challenging.

The present work deals with synthesise of 2-pyrazoline by one pot cyclic condensation of chalcone with (4-fluorophenylthio)acetic acid hydrazide (FTAH) in the presence of catalytic amount of polyphosphoric acid. The reported bioactivity of sulphur compounds led to the choice of FTAH. The structure was confirmed by FT-IR, ${ }^{1} \mathrm{H},{ }^{13} \mathrm{C}$ NMR and mass spectra. PASS analysis, an online application which predicts the biological activity spectrum of a compound based on its structure [24] was carried out for the newly synthesized 2-pyrazolines (3a-3g). It has been successfully applied in the pharmacological field.

\section{Experimental}

\subsection{Material and methods}

Chemicals and solvents used in this study were procured from Fluka, Merck and SigmaAldrich without further purification. TLC plates obtained from Merck, was used to monitor the reaction and also to establish the purity of the compounds along with melting point determination. ${ }^{1} \mathrm{H}$ NMR and ${ }^{13} \mathrm{C}$ NMR spectra were recorded on Bruker NMR spectrometer using $\mathrm{CDCl}_{3}$ and $\mathrm{DMSO}-\mathrm{d}_{6}$ as solvent. Mass spectra of all the compounds were recorded on TOF and quadrupole mass analyzer, UPLC and LCMS. FT-IR spectra were recorded using Bruckner in the range of $4000-400 \mathrm{~cm}^{-1}$.

\subsection{Synthesis of chalcones (C1-C7 / 1a-1g)}

Chalcones were prepared by Claisen-Schmidt reaction of substituted acetophenone and substituted benzaldehydes in the presence of sodium hydroxide. To an alcoholic solution of substituted acetophenone ( $1 \mathrm{mmol})$, sodium hydroxide $(2 \mathrm{mmol})$ was added and stirred to get a clear solution. To this, an alcoholic solution of the substituted aldehyde $(1 \mathrm{mmol})$ was added and the reaction was monitored through TLC. On completion of the reaction, the reaction mixture was poured into crushed ice and acidified with $\mathrm{HCl}$. The solid separated was filtered, dried and recrystallized from alcohol. (Scheme-1) 


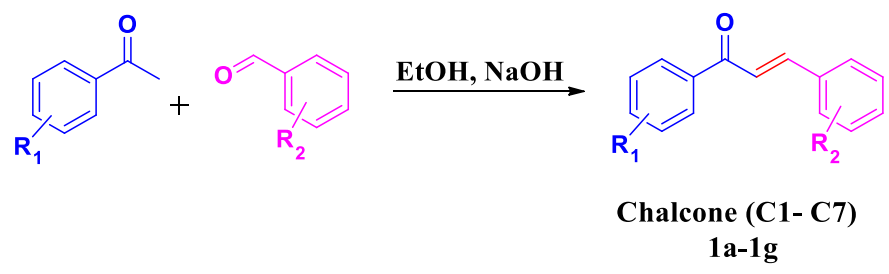

Scheme 1. Synthesis of chalcone.

3-(2, 6-dichlorophenyl)-1-(2-hydroxy-5-methylphenyl)-prop-2-en-1-one [C1/1a]

Yellow solid; IR $\left(\mathrm{KBr}, \mathrm{cm}^{-1}\right)$ : 3441.37, 2980.64, 1644.35, 1596.15, 1001.79, 741.07;

${ }^{1} \mathrm{H}$ NMR (DMSO-d $6,400 \mathrm{MHz}, \delta \mathrm{ppm}$ ): 11.60 (s, 1H,), $7.91(\mathrm{~d}, J=16.00 \mathrm{~Hz}, 1 \mathrm{H}), 7.73$ $(\mathrm{d}, J=16.00 \mathrm{~Hz}, 2 \mathrm{H}), 7.60(\mathrm{~d}, J=8.00 \mathrm{~Hz}, 2 \mathrm{H}),, 7.42-7.44(\mathrm{~m}, 1 \mathrm{H}), 7.37$ (dd, $J=2.00,8.40$ $\mathrm{Hz}, 1 \mathrm{H}), 6.92(\mathrm{~d}, J=8.40 \mathrm{~Hz}, 1 \mathrm{H}), 2.27$ (s, 3H); MS (UPLC): m/z $307.1[\mathrm{M}]^{+}, 309.1$ $[\mathrm{M}+2]+$.

3-(2, 6-dichlorophenyl)-1-(2, 4-difluorophenyl)prop-2-en-1-one [C2/1b]

White solid; IR $\left(\mathrm{KBr}, \mathrm{cm}^{-1}\right): 1664.48,1619.18,1571.58,1101.6,981.59 ;{ }^{1} \mathrm{H} \mathrm{NMR}\left(\mathrm{CDCl}_{3}\right.$, $400 \mathrm{MHz}, \delta \mathrm{ppm}): 7.65-7.95(\mathrm{~m}, 2 \mathrm{H}), 7.62(\mathrm{~d}, J=4.00 \mathrm{~Hz}, 1 \mathrm{H}), 7.39(\mathrm{~d}, J=8.00 \mathrm{~Hz}$, 2H), $7.21(\mathrm{~d}, J=16.00 \mathrm{~Hz}, 1 \mathrm{H}), 6.80(\mathrm{~d}, J=8.00 \mathrm{~Hz}, 1 \mathrm{H}), 6.65(\mathrm{~d}, J=12.00 \mathrm{~Hz}, 1 \mathrm{H})$; MS (HRMS): m/z $314[\mathrm{M}+1]+$.

1-(2, 4-difluorophenyl)-3-(3,4-dimethoxyphenyl)prop-2-en-1-one [C3/1c] Reported in literature [25].

3-(2, 6-dichlorophenyl)-1-(2, 4-dichlorophenyl)prop-2-en-1-one [C4/1d]

White solid; IR $\left(\mathrm{KBr}, \mathrm{cm}^{-1}\right)$ : 1671.25, 1605.63, 1579.26, 974.44, 773.23; ${ }^{1} \mathrm{H}$ NMR $\left(\mathrm{CDCl}_{3}, 400 \mathrm{MHz}, \delta \mathrm{ppm}\right): 7.66(\mathrm{~d}, J=16.00 \mathrm{~Hz}, 1 \mathrm{H}), 7.53(\mathrm{~d}, J=8.00 \mathrm{~Hz}, 2 \mathrm{H}), 7.39-7.40$ (m, 3H), 7.28-7.30 (m, 1H), 7.24 (d, $J=16.00 \mathrm{~Hz}, 1 \mathrm{H})$; MS (LCMS): m/z $346.8[\mathrm{M}+1]+$.

1-(2, 4-dichlorophenyl)-3-(3,4-dimethoxyphenyl)prop-2-en-1-one [C5/1e]

Available in the literature [26]

3-(2, 6-dichlorophenyl)-1-(4-iodophenyl)prop-2-en-1-one [C6/1f]

White solid; IR $\left(\mathrm{KBr}, \mathrm{cm}^{-1}\right)$ : 1671.80, 1608.6, 1579.16, 1002.49, 766.13, 548.41; ${ }^{1} \mathrm{H}$ NMR $\left(\mathrm{CDCl}_{3}, 400 \mathrm{MHz}, \delta \mathrm{ppm}\right): 7.86-7.89(\mathrm{~m}, 3 \mathrm{H}), 7.75(\mathrm{~d}, J=8.00 \mathrm{~Hz}, 2 \mathrm{H}), 7.63$ (d, $J=16.00 \mathrm{~Hz}, 1 \mathrm{H}), 7.41$ (d, $J=8.00 \mathrm{~Hz}, 2 \mathrm{H}), 7.22-7.24$ (m, 1H); MS (UPLC): $\mathrm{m} / \mathrm{z}, 403.1$ $[\mathrm{M}]+, 405.1[\mathrm{M}+2]+$.

3-(3,4-dimethoxyphenyl)-1-(4-iodophenyl)prop-2-en-1-one $[\mathrm{C} 7 / 1 \mathrm{~g}]$ Reported in the literature [27]. 


\subsubsection{Synthesis of (4-fluorophenylthio)acetic acid (FTA)}

To a solution of 4-fluorobenzenethiol and chloroacetic acid in water, $\mathrm{NaOH}$ was added till the reaction mixture became basic $(\mathrm{pH} \mathrm{12-13).} \mathrm{The} \mathrm{resultant} \mathrm{solution} \mathrm{was} \mathrm{stirred} \mathrm{at} \mathrm{reflux}$ temperature $\left(90{ }^{\circ} \mathrm{C}\right)$ for $2 \mathrm{~h}$. The reaction was monitored through TLC. After completion of reaction, it was cooled to room temperature and poured into ice. The product was separated by filtration. Observed yield was $86 \%$ (Scheme 2).

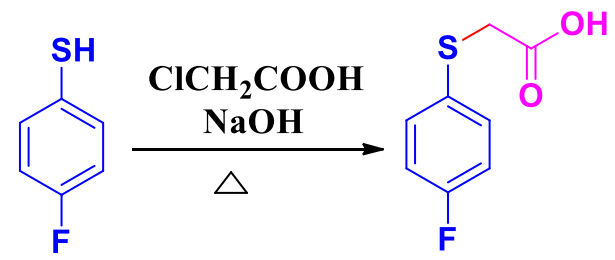

FTA

Scheme 2. Synthesis of FTA.

\subsubsection{Synthesis of ethyl ester of carboxylic acid (FTAE)}

A solution of carboxylic acid (FTA) in ethanol was cooled to $0{ }^{\circ} \mathrm{C}$ and then thionyl chloride was added. The resulting solution was stirred and refluxed for $3 \mathrm{~h}$. The reaction was monitored through TLC. After completion of the reaction, the reaction mixture was cooled to room temperature and ethanol was evaporated under vacuum. The resultant mixture was poured into ice water and the product was extracted with ethyl acetate, washed with $\mathrm{NaHCO}_{3}$, brine solution and dried over anhydrous $\mathrm{Na}_{2} \mathrm{SO}_{4}$. The solvent was evaporated under vacuum to afford the corresponding ethyl ester of carboxylic acid (FTAE). The yield was $90 \%$. (Scheme 3)
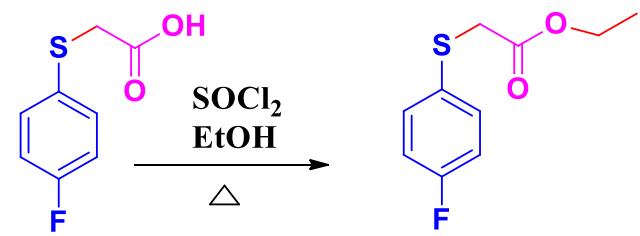

FTAE

Scheme 3. Synthesis of FTAE.

\subsubsection{Preparation of acid hydrazide FTAH (2)}

To a solution of ethyl ester (FTAE) in ethanol at room temperature, hydrazine hydrate was added and the resulting solution was stirred and refluxed for $4 \mathrm{~h}$. The reaction was monitored through TLC. After completion of reaction, the reaction mixture was cooled to room temperature and poured into ice. The product separated as solid was washed with diethyl ether and recrystallized from ethanol. Observed yield was $85 \%$. (Scheme 4) 


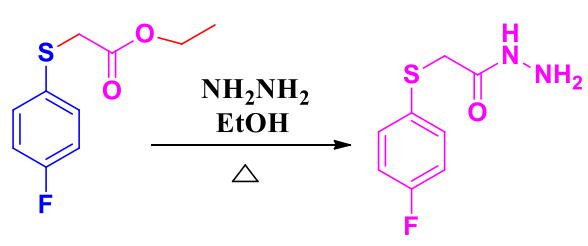

FTAH

Scheme 4. Synthesis of FTAH.

\subsubsection{Characterization of FTA}

(4-fluorophenylthio)acetic acid [FTA]

White solid; IR $\left(\mathrm{KBr}, \mathrm{cm}^{-1}\right)$ : 3300, 2910.06, 1707.66, 1094.4, 668.21; ${ }^{1} \mathrm{H}$ NMR (400 MHz, DMSO-d 6 , $\delta$ ppm): 12.72 (s, 1H), 7.40-7.45 (m, 2H), 7.13-7.20 (m, 2H), 3.75 (s, 2H); MS (LCMS): m/z 185 [M-1]+.

(4-fluorophenythio)acetic acid ethyl ester [FTAE]

Colourless liquid; IR $\left(\mathrm{KBr}, \mathrm{cm}^{-1}\right)$ : 3066.26, 2984.3, 1734.66, 1154, 1094.4, 628.68; ${ }^{1} \mathrm{H}$ NMR (400 MHz, DMSO-d 6 , $\delta$ ppm): 7.42-7.47 (m, 2H), 7.16-7.22 (m, 2H), 4.06 (q, $J=$ $7.20 \mathrm{~Hz}, 2 \mathrm{H}), 3.82$ (s, 2H), 1.12 (t, $J=7.20 \mathrm{~Hz}, 3 \mathrm{H})$; MS (LCMS): m/z $215.2[\mathrm{M}+1]+$.

(4-fluorophenylthio)acetic acid hydrazide [FTAH] (2)

White solid; IR $\left(\mathrm{KBr}, \mathrm{cm}^{-1}\right)$ : 3299.70, 3269.72, 3044.09, 1663.3, 1590.02, 1328.71, 1090.55, 992, 961, 626.75; ${ }^{1} \mathrm{H}$ NMR (400 MHz, DMSO - d 6 , $\delta$ ppm): 9.19 (s, 1H), 7.42$7.45(\mathrm{~m}, 2 \mathrm{H}), 7.14-7.19(\mathrm{~m}, 2 \mathrm{H}), 4.26(\mathrm{~d}, J=6.40 \mathrm{~Hz}, 2 \mathrm{H}), 3.31(\mathrm{~s}, 2 \mathrm{H})$; MS (UPLC): $[\mathrm{ES}+] \mathrm{m} / \mathrm{z} 201.1[\mathrm{M}]+$.

\subsection{Synthesis of 2-pyrazoline derivatives (P1-P7/ 3a-3g)}

A mixture of chalcone $(1 \mathrm{mmol})$ and FTAH $(1 \mathrm{mmol})$ in glacial acetic acid containing catalytic amount of PPA was refluxed. The reaction was monitored through TLC and after completion, the reaction mixture was poured into crushed ice. The solid formed was filtered, dried and purified through column chromatography using 60-120 silica gel and hexane - ethyl acetate as eluent. Observed yields were in the range of $65-70 \%$ (Scheme 5). 


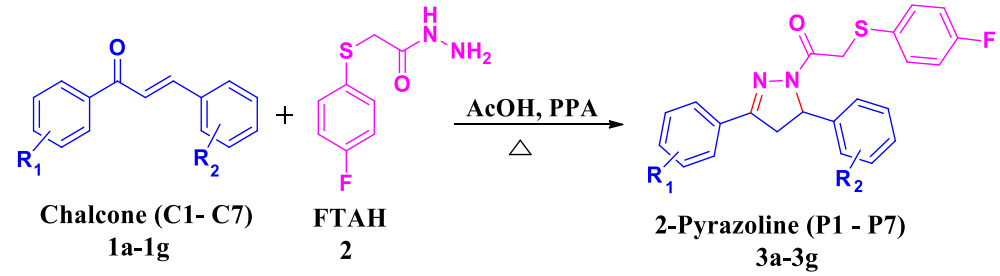

Scheme 5. Synthesis of pyrazoline P1-P7/3a-3g.

1-(5-(2,6-dichlorophenyl)-3-(2-hydroxy-5-methylphenyl)-4,5-dihydro-1Hpyrazol-1-yl)-2(4-fluorophenylthio)ethanone [P1/3a]

Yellow solid; IR (KBr, $\left.\mathrm{cm}^{-1}\right)$ : 3174.05, 3070, 2913.85, 1655.2, 1580.09, 1187.58, 134.91, 1088.43, 783.13, 676.82; ${ }^{1} \mathrm{H} \mathrm{NMR}\left(\mathrm{CDCl}_{3}, 400 \mathrm{MHz}, \delta \mathrm{ppm}\right): 10.41$ (s, 1H), 7.87 (d, $J=$ $8.00 \mathrm{~Hz}, 1 \mathrm{H}), 7.38-7.39(\mathrm{~m}, 4 \mathrm{H}), 7.30-7.32(\mathrm{~m}, 2 \mathrm{H}), 7.05(\mathrm{~d}, J=8.00 \mathrm{~Hz}, 1 \mathrm{H}), 6.91-6.75-$ $6.93(\mathrm{~m}, 2 \mathrm{H}), 5.74(\mathrm{dd}, J=4.00,12.00 \mathrm{~Hz}, 1 \mathrm{H}), 3.84(\mathrm{dd}, J=12.80,18.00 \mathrm{~Hz}, 1 \mathrm{H}), 3.42(\mathrm{~s}$, $2 \mathrm{H}), 3.32(\mathrm{dd}, J=4.80,17.00 \mathrm{~Hz}, 1 \mathrm{H}), 2.51(\mathrm{~s}, 3 \mathrm{H}) ;{ }^{13} \mathrm{C} \mathrm{NMR}\left(\mathrm{CDCl}_{3}, 100 \mathrm{MHz}, \delta \mathrm{ppm}\right)$ $169.68,160.74,157.00,151.71,144.47,133.44,128.4,59.07,39.83,39.41,27.07$; MS (HRMS): m/z $489.05[\mathrm{M}]+$.

1-(5-(2,6-dichlorophenyl)-3-(2,4-difluorophenyl)-4,5-dihydro-1H-pyrazol-1-yl)-2-(4fluoro phenylthio)ethanone [P2/3b]

White solid; IR $\left(\mathrm{KBr}, \mathrm{cm}^{-1}\right)$ : 3060.48, 2922.59, 1686.44, 1495.53, 1132.97, 1098.51, 1034.62, 851.23, 693.28, 464.76; ${ }^{1} \mathrm{H} \mathrm{NMR}\left(\mathrm{CDCl}_{3}, 400 \mathrm{MHz}, \delta \mathrm{ppm}\right): 7.49-7.50$ (m, $\left.2 \mathrm{H}\right)$, 7.32-7.40 (m, 1H), 7.26-7.28 (m, 3H), 7.09-7.09 (m, 2H), 6.87-6.96 (m, 1H), $6.74(\mathrm{~d}, J=$ $8.00 \mathrm{~Hz}, 1 \mathrm{H}), 5.43$ (dd, $J=4.00,12.00 \mathrm{~Hz}, 1 \mathrm{H}), 4.09$ (dd, $J=11.60,17.80 \mathrm{~Hz}, 1 \mathrm{H}), 3.68$ $(\mathrm{dd}, J=12.00,18.00 \mathrm{~Hz}, 1 \mathrm{H}), 3.40(\mathrm{~s}, 2 \mathrm{H}) ;{ }^{13} \mathrm{C}-\mathrm{NMR}\left(\mathrm{CDCl}_{3}, 100 \mathrm{MHz}, \delta \mathrm{ppm}\right): 170.4$, $164.2,162.2,156,130.9,64.42,39.7,36.8$.

1-(3-(2,4-difluorophenyl)-5-(3,4-dimethoxyphenyl)-4,5-dihydro- $1 H$-pyrazol-1-yl)-2-((4fluorophenylthio)ethanone $[\mathrm{P} 3 / 3 \mathrm{c}]$

Yellow solid; IR $\left(\mathrm{KBr}, \mathrm{cm}^{-1}\right)$ : 2933.2, 1668.12, 1589.06, 1141.65, 1109.83, 1026.91, 604.41; ${ }^{1} \mathrm{H}$ NMR $\left(\mathrm{CDCl}_{3}, 400 \mathrm{MHz}, \delta \mathrm{ppm}\right): 7.71(\mathrm{~d}, \mathrm{~J}=6.40 \mathrm{~Hz}, 2 \mathrm{H}), 7.46(\mathrm{~d}, J=1.60$ $\mathrm{Hz}, 2 \mathrm{H}), 7.30-7.30(\mathrm{~m}, 2 \mathrm{H}), 6.77-6.79(\mathrm{~m}, 4 \mathrm{H}), 5.53(\mathrm{dd}, J=4.00,12.60 \mathrm{~Hz}, 1 \mathrm{H}), 3.90$ (dd, $J=12.00,18.00 \mathrm{~Hz}, 1 \mathrm{H}), 3.86(\mathrm{~s}, 3 \mathrm{H}), 3.84(\mathrm{~s}, 3 \mathrm{H}), 3.51(\mathrm{~s}, 2 \mathrm{H}) 3.35$ (dd, $J=4.00$, $18.00 \mathrm{~Hz}, 1 \mathrm{H}) ;{ }^{13} \mathrm{C}$ NMR (DMSO-d $\left.6,100 \mathrm{MHz}, \delta \mathrm{ppm}\right): 169.2,163,161,159,155.58$, 149.3, 148.7, 60.2, 56.05, 45.12, 29.78; MS (HRMS): m/z 486.23 [M+H]+.

1-(3-(2,4-dichlorophenyl)-5-(2,6-dichlorophenyl)-4,5-dihydro-1 $H$-pyrazol-1-yl)-2-(4fluoro phenylthio)ethanone [P4/3d]

Yellow solid; IR $\left(\mathrm{KBr}, \mathrm{cm}^{-1}\right)$ : 3164.21, 3080.75, 2924.85, 1671.36, 1591.46, 1199.13 1145.43, 1098.86, 774.51, 681.54; ${ }^{1} \mathrm{H}$ NMR $\left(\mathrm{CDCl}_{3}, 400 \mathrm{MHz}, \delta \mathrm{ppm}\right): 8.16(\mathrm{~d}, J=7.20$ $\mathrm{Hz}, 2 \mathrm{H}), 7.84(\mathrm{~d}, J=8.40 \mathrm{~Hz}, 2 \mathrm{H}), 7.66-7.68(\mathrm{~m}, 2 \mathrm{H}), 7.58(\mathrm{~m}, J=7.20 \mathrm{~Hz}, 2 \mathrm{H}), 7.33(\mathrm{~d}$, $J=8.40 \mathrm{~Hz}, 2 \mathrm{H}), 5.22(\mathrm{dd}, J=4.40,12.00 \mathrm{~Hz}, 1 \mathrm{H}), 3.88(\mathrm{dd}, J=11.60,18.00 \mathrm{~Hz}, 1 \mathrm{H})$, 
$3.57(\mathrm{~s}, 2 \mathrm{H}) 3.16(\mathrm{dd}, J=4.40,18.40 \mathrm{~Hz}) ;{ }^{13} \mathrm{C} \mathrm{NMR}\left(\mathrm{CDCl}_{3}, 100 \mathrm{MHz}, \delta \mathrm{ppm}\right): 170.74$, 154.24, 153.17, 134.79, 131.24, 130.97, 129.24, 60.65, 36.91, 36.77; MS (HRMS): m/z $528.96[\mathrm{M}+\mathrm{H}]+$.

1-(3-(2,4-dichlorophenyl)-5-(3,4-dimethoxyphenyl)-4,5-dihydro-1 $H$-pyrazol-1-yl)-2-(4fluorophenylthio)ethanone [P5/3e]

Yellow solid; IR $\left(\mathrm{KBr}, \mathrm{cm}^{-1}\right)$ : 3069.16, 2937.06, 1669.09, 1588.09, 1142.62, 1109.83, 1027.87, 763.67, 612.28; ${ }^{1} \mathrm{H}$ NMR $\left(\mathrm{CDCl}_{3}, 400 \mathrm{MHz}, \delta \mathrm{ppm}\right): 7.65$ (d, $\left.J=1.20 \mathrm{~Hz}, 1 \mathrm{H}\right)$, 7.62-7.63 (m, 2H), 7.23-7.23 (m, 3H), 6.70-6.71 (m, 4H), $5.47(\mathrm{dd}, J=4.00,11.20 \mathrm{~Hz}$, $1 \mathrm{H}), 3.84(\mathrm{dd}, J=12.00,16.00 \mathrm{~Hz}, 1 \mathrm{H}), 3.77$ (s, 3H), 3.76 (s, 3H), 3.5 (s, 2H), 3.28 (dd, $J$ $=4.00,16.00 \mathrm{~Hz}, 1 \mathrm{H}) ;{ }^{13} \mathrm{C} \mathrm{NMR}\left(\mathrm{CDCl}_{3}, 100 \mathrm{MHz}, \delta \mathrm{ppm}\right): 169.2,158.02,156.2,149.3$, 148.7, 134.1, 129.3, 127.5, 60.2, 56.0, 45.0, 31.7; MS (HRMS): m/z 519.12 [M+H]+.

1-(5-(2,6-dichlorophenyl)-3-(4-iodophenyl)-4,5-dihydro-1 $H$-pyrazol-1-yl)-2-(4-

fluorophenyl thio)ethanone [P6/3f]

White solid; IR $\left(\mathrm{KBr}, \mathrm{cm}^{-1}\right)$ : 3085.96, 2986.21, 1669.66, 1588.17, 1196.16, 1098.02, 1060.78, 881.07, 614.45, 454.98; ${ }^{1} \mathrm{H}$ NMR (DMSO-d 6 , $\left.400 \mathrm{MHz}, \delta \mathrm{ppm}\right): 8.13$ (d, $J=$ $8.00 \mathrm{~Hz}, 2 \mathrm{H}), 7.49-7.68(\mathrm{~m}, 4 \mathrm{H}), 7.28-7.33(\mathrm{~m}, 1 \mathrm{H}), 7.01-7.04(\mathrm{~m}, 4 \mathrm{H}), 5.52(\mathrm{dd}, J=$ $4.80,11.60 \mathrm{~Hz}, 1 \mathrm{H}), 3.54(\mathrm{dd}, J=12.00,18.00 \mathrm{~Hz}, 1 \mathrm{H}), 3.41(\mathrm{~s}, 2 \mathrm{H}), 3.28$ (dd, $J=4.00$, $18.00 \mathrm{~Hz}, 1 \mathrm{H}$ ); ${ }^{13} \mathrm{C}$ NMR (DMSO-d 6 , $100 \mathrm{MHz}, \delta \mathrm{ppm}$ ) : 170.65, 158.41, 155.31, 133.85, 128.78, 97.60, 60.65, 36.89, 36.54; MS (HRMS): m/z 584.94 [M+H]+', 606.92 [M+Na]+.

1-(5-(3,4-dimethoxyphenyl)-3-(4-iodophenyl)-4,5-dihydro-1H-pyrazol-1-yl)-2-((4-fluoro phenyl)thio)ethanone [P7/3g]

Yellow solid; IR $\left(\mathrm{KBr}, \mathrm{cm}^{-1}\right)$ 2923.56, 1659.45, 1589.06, 1142.62 , 1027.87, 1027.87, 614.21, 444.51; ${ }^{1} \mathrm{H}$ NMR $\left(\mathrm{CDCl}_{3}, 400 \mathrm{MHz}, \delta \mathrm{ppm}\right): 7.77$ (d, J = 8.40 Hz, 2H), 7.40-7.41 $(\mathrm{m}, 4 \mathrm{H}), 6.89-6.90(\mathrm{~m}, 2 \mathrm{H}), 6.75-6.75(\mathrm{~m}, 3 \mathrm{H}), 5.53(\mathrm{dd}, J=4.00,11.40 \mathrm{~Hz}, 1 \mathrm{H}), 3.98$ (dd, J = 12.00, $18.40 \mathrm{~Hz}, 1 \mathrm{H}), 3.96$ (s, 3H), 3.79 (s, 3H), 3.17 (dd, $J=4.80,15.80 \mathrm{~Hz}$, $1 \mathrm{H}), 3.3$ (s, 2H); ${ }^{13} \mathrm{C} \mathrm{NMR}\left(\mathrm{CDCl}_{3}, 100 \mathrm{MHz}, \delta \mathrm{ppm}\right): 167.0,157.13,153.8,149.4,148.7$, 133.2, 97.0, 60.1, 56.08, 56.04, 42.2, 29.83; MS (HRMS): m/z 598.801 [M+Na]+., $576.811[\mathrm{M}+\mathrm{H}]+$.

\subsection{PASS analysis}

The newly synthesised 2-pyrazolines (3a-3g) were submitted to PASS server in MOL file format and the biological activity was predicted [24] and is shown in Fig. 4.

Web: http://www.pharmaexpert.ru/passonline/

\section{Results and Discussion}

Chalcones (1a-1g) were prepared by Claisen-Schmidt reaction, carried out with substituted acetophenone (2-hydroxy-5-methyl acetophenone; 2,4-difluoro acetophenone; 
2,4-dichloro acetophenone; 4-iodo acetophenone) and substituted benzaldehydes (2,6dichlorobenzaldehyde; 3,4-dimethoxy benzaldehyde) in the presence of sodium hydroxide. All the reactions gave chalcones with the yield in the range of 75-82\% as illustrated in Table 1.

The structure of chalcones were well characterised by FT-IR, ${ }^{1} \mathrm{H}$ NMR and mass spectra. All chalcones (1a-1h) gave the characteristic IR peaks in the range 1640-1672 $\mathrm{cm}^{-1}$ and $1605-1619 \mathrm{~cm}^{-1}$ corresponding to $\mathrm{C}=\mathrm{O}$ stretching and $\mathrm{C}=\mathrm{C}$ stretching of $\alpha: \beta$ unsaturated carbonyl group. ${ }^{1} \mathrm{H}$ NMR spectra of chalcones showed two doublets in the olefinic range of $\delta$ 6.6-7.1 $\mathrm{ppm}$ and 7.2-7.9 ppm corresponding to $\alpha$ and $\beta$ hydrogens of chalcones. The $\mathrm{m} / \mathrm{z}$ values confirm the molecular weight of the respective chalcones (1a1g) (Fig. 1).

Table 1. Yield and melting point of chalcones (1a-1g).

\begin{tabular}{|c|c|c|c|c|c|}
\hline S. No & Chalcone & $\mathrm{R}_{1}$ & $\mathrm{R}_{2}$ & Yield (\%) & Melting point $\left({ }^{\circ} \mathrm{C}\right)$ \\
\hline 1 & $\mathrm{C} 1 / 1 \mathrm{a}$ & $2-\mathrm{OH}-5-\mathrm{CH}_{3}$ & $2-\mathrm{Cl}-6-\mathrm{Cl}$ & 82 & 148 \\
\hline 2 & $\mathrm{C} 2 / 1 \mathrm{~b}$ & 2-F-4-F & 2-Cl-6-Cl & 76 & 94 \\
\hline 3 & $\mathrm{C} 3 / 1 \mathrm{c}$ & 2-F-4-F & $3-\mathrm{OCH}_{3}-4-\mathrm{OCH}_{3}$ & 78 & 105 \\
\hline 4 & $\mathrm{C} 4 / 1 \mathrm{~d}$ & $2-\mathrm{Cl}-4 \mathrm{Cl}$ & 2-Cl-6-Cl & 75 & 137 \\
\hline 5 & $\mathrm{C} 5 / 1 \mathrm{e}$ & $2-\mathrm{Cl}-4 \mathrm{Cl}$ & $3-\mathrm{OCH}_{3}-4-\mathrm{OCH}_{3}$ & 80 & 136 \\
\hline 6 & $\mathrm{C} 6 / 1 \mathrm{f}$ & 4-I & 2-Cl-6-Cl & 80 & 116 \\
\hline 7 & C7/1g & 4-I & $3-\mathrm{OCH}_{3}-4-\mathrm{OCH}_{3}$ & 78 & 133 \\
\hline
\end{tabular}<smiles>Cc1ccc(O)c(C(=O)/C=C/c2c(Cl)cccc2Cl)c1</smiles>

C1/1a<smiles>O=C(/C=C/c1c(Cl)cccc1Cl)c1ccc(F)cc1F</smiles>

C2/1b<smiles>COc1ccc(/C=C/C(=O)c2ccc(F)cc2F)cc1OC</smiles>

C3/1c<smiles>O=C(/C=C/c1c(Cl)cccc1Cl)c1ccc(Cl)cc1Cl</smiles>

C4/1d<smiles>O=C(/C=C/c1c(Cl)cccc1Cl)c1ccc(I)cc1</smiles>

C6/1f<smiles>O=C(/C=C/c1ccc2c(c1)OCCO2)c1ccc(Cl)cc1Cl</smiles>

C5/1e

Fig. 1. Structure of chalcones C1-C7/1a-1g.

The FTAH (2) was prepared from 4-fluorothiophenol in three steps. In the first step a mixture of 4-flurothiophenol, 2-chloroacetic acid and sodium hydroxide was refluxed for $2 \mathrm{~h}$, yield of FTA was $86 \%$ (Scheme 2). Second step involves, refluxing a mixture of FTA, $\mathrm{SOCl}_{2}$ in ethanol for $3 \mathrm{~h}$ yielding $90 \%$ of FTAE (Scheme 3). In the last step, a 
mixture of FTAE, $\mathrm{NH}_{2} \mathrm{NH}_{2}$ in ethanol was refluxed for $4 \mathrm{~h}$ which yielded $85 \%$ of FTAH (2) (Scheme 4). As this hydrazide has not yet been reported in literature systematic spectral characterization of the acid (FTA), ester (FTAE) and hydrazide (FTAH) were carried out by FT-IR, ${ }^{1} \mathrm{H}$ NMR and mass spectra.

${ }^{1} \mathrm{H}$ NMR spectrum of the hydrazide showed peaks at $9.19 \mathrm{ppm}(\mathrm{s}, 1 \mathrm{H})$ corresponding to $-\mathrm{CONH}$, at $4.26 \mathrm{ppm}(\mathrm{s}, 2 \mathrm{H})$ corresponding to the $-\mathrm{NH}_{2}$ group, $3.31 \mathrm{ppm}(\mathrm{s}, 2 \mathrm{H})$ corresponds to $-\mathrm{CH}_{2}$ flanked between $\mathrm{S}$ and $-\mathrm{CONHNH}_{2}$ apart from aromatic protons. IR spectrum showed absorption at 3299.7 and $3269.7 \mathrm{~cm}^{-1}$ corresponding to N-H stretching and $1663 \mathrm{~cm}^{-1}$ corresponding to amide carbonyl stretching. HRMS additionally confirms the formation of the compound by the (M+) peak at m/z 201.1 [FTAH] (2).

Refluxing of chalcone (1a-1g) and 4-fluorophenylthio hydrazide [FTAH] (2) in glacial acetic acid containing catalytic amount of poly phosphoric acid (PPA) yielded new-2pyrazolines via cyclocondensation [28] (Scheme 5). Products formed were characterized by spectral data. Yield of 2-pyrazolines formed with their respective structures are presented in Table 2.

Table 2. Yield of 2-pyrazolines.

\begin{tabular}{cccc}
\hline S. No & 2-pyrazolines & Yield $(\%)$ & Melting point $\left({ }^{\circ} \mathrm{C}\right)$ \\
\hline 1 & $\mathrm{P} 1 / 3 \mathrm{a}$ & 67 & 201 \\
2 & $\mathrm{P} 2 / 3 \mathrm{~b}$ & 65 & 158 \\
3 & $\mathrm{P} 3 / 3 \mathrm{c}$ & 66 & 160 \\
4 & $\mathrm{P} 4 / 3 \mathrm{~d}$ & 70 & 165 \\
5 & $\mathrm{P} 5 / 3 \mathrm{e}$ & 66 & 176 \\
6 & $\mathrm{P} 6 / 3 \mathrm{f}$ & 69 & 156 \\
7 & $\mathrm{P} 7 / 3 \mathrm{~g}$ & 67 & 210 \\
\hline
\end{tabular}

The synthesized 2-pyrazolines (3a-3g) showed the characteristic FT-IR peaks at 1656$1686 \mathrm{~cm}^{-1}$ corresponding to carbonyl group stretching, $1495-1591 \mathrm{~cm}^{-1}$ for $-\mathrm{C}=\mathrm{N}-$ stretching, $1132-1199 \mathrm{~cm}^{-1}$ for $-\mathrm{C}-\mathrm{N}-$ stretching. In ${ }^{1} \mathrm{H}$ NMR spectrum of 2-pyrazolines, the doublet of doublet at $\delta 3.17-3.7 \mathrm{ppm}$ is assigned to $\mathrm{H}_{\mathrm{a}}$ proton of $\mathrm{C}-4$ with coupling constants $J=16-18.4 \mathrm{~Hz}$ corresponding to geminal coupling by $\mathrm{H}_{\mathrm{b}}$ proton of C-4 and $J=4$ $-4.8 \mathrm{~Hz}$ for the vicinal coupling by $\mathrm{H}_{\mathrm{c}}$ proton of $\mathrm{C}-5$. The doublet of doublet at 3.9 to 4.9 ppm is assigned to $\mathrm{H}_{\mathrm{b}}$ proton of $\mathrm{C}-4$ with coupling constants, $J=17.8-18.4 \mathrm{~Hz}$ corresponding to geminal coupling by $\mathrm{H}_{\mathrm{a}}$ proton of $\mathrm{C}-4$ and $J=11.6-12 \mathrm{~Hz}$ for the vicinal coupling by $\mathrm{H}_{\mathrm{c}}$ of $\mathrm{C}-5$. Similarly, the doublet of doublet at 5.22 to $5.74 \mathrm{ppm}$ is assigned to $\mathrm{H}_{\mathrm{c}}$ proton of $\mathrm{C}-5$ with coupling constants $J=11.2-12.6 \mathrm{~Hz}$ corresponding to vicinal coupling by $\mathrm{H}_{\mathrm{b}}$ of $\mathrm{C}-4$ and $J=4-4.8 \mathrm{~Hz}$ for the vicinal coupling by $\mathrm{H}_{\mathrm{a}}$ of $\mathrm{C}-4$. The singlet at $3 \mathrm{ppm}$ is assigned to $-\mathrm{CH}_{2}$ proton, which is flanked between $\mathrm{S}$ and carbonyl group. The aromatic protons appeared in the range of 6.71 to $8.21 \mathrm{ppm}$. Thus proton NMR confirms the formation of 2-pyrazoline in the cyclocondensation. ${ }^{13} \mathrm{C}$ NMR peaks at $\delta$ 167-170 ppm corresponding to carbonyl carbon, 151-156 ppm for $-\mathrm{C}=\mathrm{N}-$ carbon $(\mathrm{C} 3$ carbon), 56-64 ppm for $-\mathrm{C}-\mathrm{N}$ - carbon (C5) and 36-42 ppm for C4 carbon of 2pyrazolines rings, thus the spectral data support and confirm the structure of 2-pyrazolines (3a-3g). 
The $m / z$ values confirm the molecular weight of the respective 2-pyrazolines $(\mathbf{3 a}-\mathbf{3 g})$. The structures of pyrazolines and numbering are shown in Figs. 2 and 3.

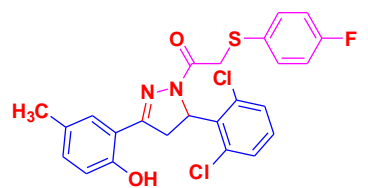

P1/3a

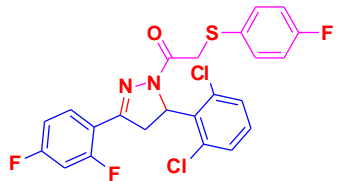

$\mathbf{P 2} / 3 \mathrm{~b}$<smiles>COc1ccc(C2CC(c3ccc(F)cc3F)=NN2C(=O)CSc2ccc(F)cc2)cc1</smiles>

P3/3c

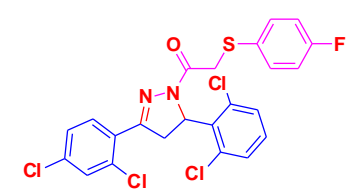

$\mathbf{P 4 / 3 d}$

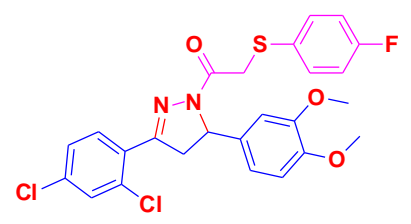

P5/3e

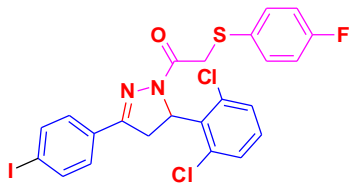

P6/3f

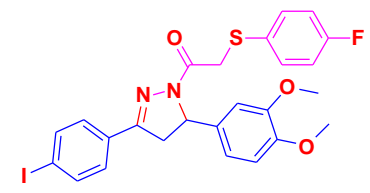

P7/3g

Fig. 2. Structure of pyrazolines P1-P7/3a-3h.

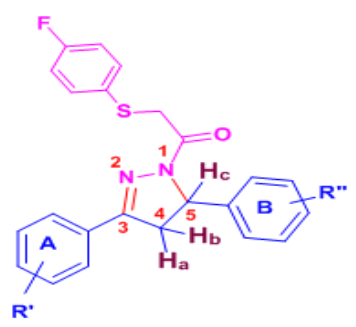

Fig. 3. Numbering of 2-pyrazoline.

The newly synthesized 2-pyrazolines were subjected to PASS prediction for their biological activity as shown in Fig. 4. All the 2-pyrazolines (3a-3g) show, Nicotinic $\alpha 4 \beta 4$ receptor agonist [29] activity due to which, it is expected to increase $\mathrm{Na}^{+}, \mathrm{K}^{+}$permeability. The PfA-M1 amino peptidase inhibitor activity [30] of the 2-pyrazolines (3a-3g) could be used for the treatment of a range of condition including malaria, hypertension and cancer, apart from this it is expected to have analgesic action. 


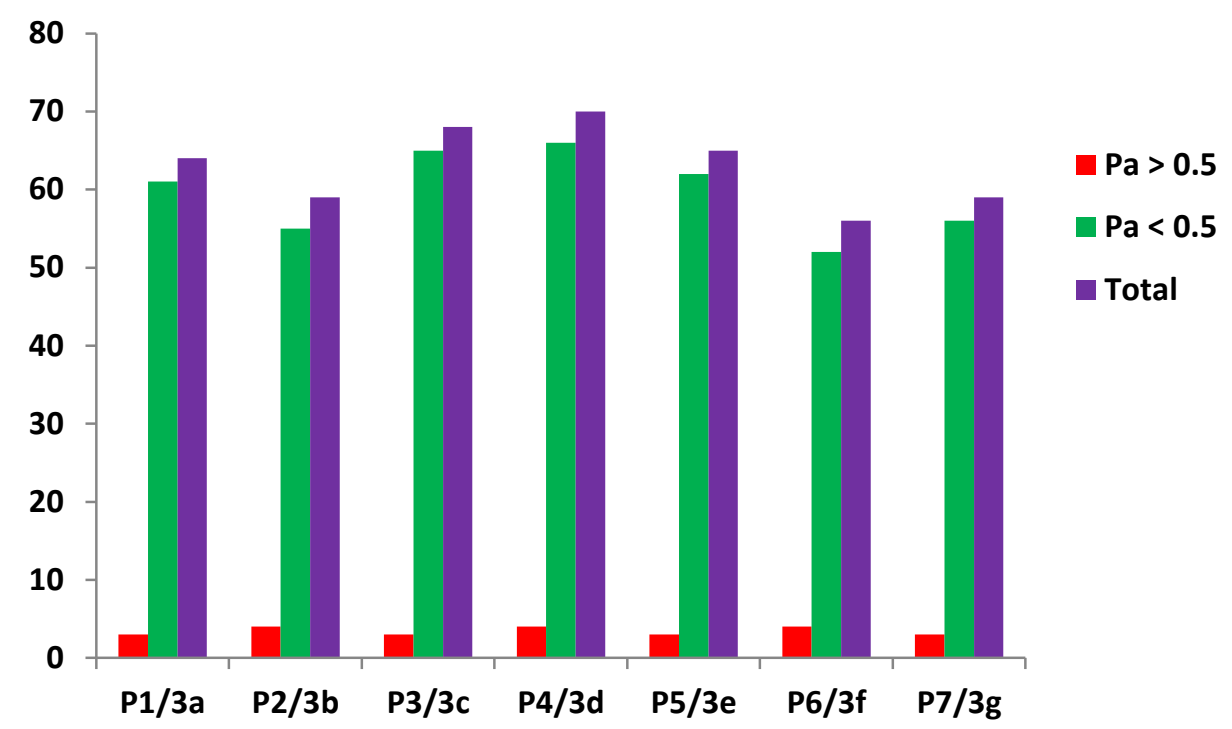

Fig. 4. PASS activity of 2-pyrazoline.

\section{Conclusion}

New 2-pyrazolines (3a-3g) were synthesised by cyclocondensation reaction of chalcones (1a-1g) with FTAH (2) in the presence of PPA with isolated yield in the range of 65-70 $\%$. All the compounds were characterised by FT-IR, ${ }^{1} \mathrm{H},{ }^{13} \mathrm{C}$ NMR and mass spectra. InSilico biological activity was predicted by PASS analysis; it shows that all the compounds have good pharmacological activity. Future study demands in vitro and in vivo studies of newly synthesised 2-pyrazolines.

\section{Acknowledgment}

Financial assistance from University Grants Commission, Hyderabad, India is gratefully acknowledged.

\section{References}

1. L. C. Raiford and R. H. Manley, J. Org. Chem. 5, 590 (1940). https://doi.org/10.1021/jo01212a004

2. B. Bhat, K. Dhar, S. Puri, A. Saxena, M. Shanmugavel, and G. Qazi, Bioorg. Med. Chem. Lett. 15, 3177 (2005). https://doi.org/10.1016/j.bmcl.2005.03.121

3. G. Shenoy, A. Bhat, G. Bhat, and M. Kotian, Ind. J. Heterocycl. Chem. 10, 197 (2001).

4. B. De, S. Sen, and T. Easwari, Asian J. Res. Chem. 5, 1482 (2012).

5. S. Drabu, A. Rana, and H. Kumar, Ind. J. Heterocycl. Chem. 16, 399 (2007).

6. F. F. Barsoum, H.M. Hosni, and A. S. Girgis, Bioorg. Med. Chem. Lett. 14, 3929 (2006). https://doi.org/10.1016/j.bmc.2006.01.042 
7. V. H. Babu, C. Sridevi, A. Joseph, and K. Srinivasan, Ind. J. Pharm. Sci. 69, 470 (2007). https://doi.org/10.4103/0250-474X.34569

8. M. Abid and A. Azam, Eur. J. Med. Chem. 40, 935 (2005). https://doi.org/10.1016/j.ejmech.2005.03.015

9. J. J. Traverso, C. W. Whitehead, J. F. Bell, H. E. Boaz, and P. W. Willard, J. Med. Chem. 10, 840 (1967). https://doi.org/10.1021/jm00317a018

10. E. Palaska, D. Erol, and R. Demirdamar, Eur. J. Med. Chem. 31, 43 (1996). https://doi.org/10.1016/S0223-5234(96)80005-5

11. M. Husain and S. Shukla, Chem. Inform. 18, (1987). https://doi.org/10.1002/chin.198710221

12. V. K. Tandon, D. B. Yadav, A. K. Chaturvedi, and P. K. Shukla, Bioorg. Med. Chem. Lett. 15, 3288 (2005).

13. S. Chimichi, M. Boccalini, M. M. Hassan, G. Viola, F. Dall'Acqua, and M. Curini, Tetrahedron 62, 90 (2006). https://doi.org/10.1016/j.tet.2005.09.135

14. B. Holla, B. Veerendra, M. Shivananda, K. Latha, and V. Vaidya, Ind. J. Heterocycl. Chem. 12, 385 (2003).

15. M. Amir, H. Kumar, and S. A. Khan, Bioorg. Med. Chem. Lett. 18, 918 (2008). https://doi.org/10.1016/j.bmcl.2007.12.043

16. M. A. Rahman and A. A. Siddiqui, Int. J. Pharm. Sci. Res. 2, 165 (2010).

17. R. M. Ezhilarasi, N. Jayachandramani, and S. Mahalakshmi, IJMCA 5, 93 (2015).

18. M. A. Rahim, M. M. H. Bhuiayan, and M. M. Matin, J. Sci. Res. 12, 673 (2020). https://doi.org/10.3329/jsr.v12i4.45523

19. B. T. Jothikrishnan and S. S. Shafi, Molbank 3, M613 (2009). https://doi.org/10.3390/M613

20. N. M. Kuz'menok, T. A. Koval'chuk, and A. M. Zvonok, Synlett 03, 485 (2005).

21. J. -T. Li, X. -H. Zhang, and Z. -P. Lin, Beilstein J. Org. Chem. 3, 13 (2007).

22. A. Lévai and J. Jeko, Arkivoc 1, 134 (2007). https://doi.org/10.3998/ark.5550190.0008.114

23. A. Saha, R. Kumar, R. Kumar, and C. Devakumar, Ind. J. Chem 49B, 526 (2010).

24. M. M. Matin, A. R. Nath, O. Saad, M. M. H. Bhuiyan, S. B. A. Hamid, A. A. Alhadi, F. A. Kadir, M. E. Ali, and W. A. Yehye, Int. J. Mol. Sci. 17, 1442 (2016). https://doi.org/10.3390/ijms17091412

25. J. Rojas, M. Payá, J. N. Dominguez, and M. L. Ferrandiz, Bioorg. Med. Chem. Lett. 12, 1951 (2002). https://doi.org/10.1016/S0960-894X(02)00317-7

26. T. Narender and K. P. Reddy, Tetrahedron Lett. 48, 3177 (2007). https://doi.org/10.1016/j.tetlet.2007.03.054

27. N. Sharma, D. Mohanakrishnan, A. Shard, A. Sharma, A. K. Sinha, and D. Sahal, J. Med. Chem. 55, 297 (2012). https://doi.org/10.1021/jm201216y

28. R. M. Ezhilarasi, N. Jayachandramani, and S. Mahalakshmi, IJACSA 3, 2 (2015).

29. L. M. Houlihan, Y. Slater, D. L. Guerra, J. H. Peng, Y. P. Kuo, R. J. Lukas, B. K. Cassels, and I. Bermudez, J. Neurochem. 78, 1029 (2001). https://doi.org/10.1046/j.14714159.2001.00481.x

30. N. Drinkwater, J. Lee, W. Yang, T. R. Malcolm, and S. McGowan, FEBS J. 284, 1473 (2017). https://doi.org/10.1111/febs.14009 